\title{
Nested PCR and Conventional Techniques for Detection of Salmonella spp. in River Nile Water, Egypt
}

\author{
Gamila E. El-Taweel, Tarek A. A. Moussa*, F.A. Samhan, \\ W.M. El-Senousy and M.A. El-Lathy ${ }^{\#}$ \\ Water Pollution Research Department, Environmental Research \\ Division, National Research Centre, Dokki and *Botany \\ Department, Faculty of Science, Cairo University, Giza, Egypt.
}

\begin{abstract}
7 HIS STUDY aimed to detect salmonellae group using most probable number (MPN), membrane filtration (MF) and nested PCR techniques from River Nile at Cairo segment and Rossita branch so, 74 samples were collected and analyzed to count the total viable bacteria/ml and total salmonellae. Total viable bacterial counts ranged from $1.0 \times 10^{2}$ to $1.6 \times 10^{8} \mathrm{cfu} / \mathrm{m} 1$ during the study. Using MPN technique salmonellae were detected in 64 samples out of 74 samples ( $86.4 \%$ recovery), with the MF technique, salmonellae were detected in 73 samples out of 74 samples and with PCR technique salmonellae were detected in all samples. It can be concluded that MF technique is more suitable to detect salmonellae as it allows to filter or pass relatively larger amount of water sample rather than MPN which measure salmonellae presence in fixed amount of water while nested PCR technique is more rapid, sensitive and specific than conventional techniques (i.e., MF and MPN). Statistical analysis were done only between MF and MPN techniques due to PCR technique doesn't provide counts to be involved in statistical analysis (provide only positive and negative results). Results indicated that counts of Salmonella showed significant differences between sites using both techniques MF and MPN at Cairo segment. Wherever, no significant difference between sites at Rossita branch.
\end{abstract}

Keywords: River Nile, Salmonella, MPN technique, MF technique, PCR technique.

River Nile is the lifeblood of Egypt. The river is the main source of freshwater for household use and irrigation, a source of power from the hydroelectric facility at Aswan, and a mean of transportation for people and goods. According to the geographical features, the administrative boundaries and the human activities, the River Nile divided into seven segments. Cairo segment is considered the most important one because it represents the major cluster of drinking water treatment plants.

"Corresponding author: Phone (+2) 0125110975. E-Mail: mohamedazabr@yahoo.com 
Surface water may play an important role in the transmission of pathogenic microbes that arrive in this water via domestic wastewater and it can return to humans by various ways, such as the use of these water for recreation or sporting (swimming or fishing), for the irrigation of vegetables and fruit trees and as a source of drinking water (Kamel et al., 2006).

Salmonella spp. are ubiquitous enteric bacteria. These Gram negative rods are the etiologic agents of waterborne salmonellosis and also the agents that cause typhoid and paratyphoid fevers. Salmonella is a prime example of a water transmitted pathogen. Salmonella is a leading cause of morbidity and mortality due to food and waterborne diseases in developed and developing world causes gastroenteritis and typhoid in humans (Malorny et al., 2008). The typhoid caused by Salmonella enterica serotype Typhi remains an important public health problem in developing countries. In 2000, it was estimated that over 2.16 million episodes of typhoid occurred worldwide, resulting in 216,000 deaths and that more than $90 \%$ of this morbidity and mortality occurred in Asia (Crump et al., 2004). Further, Salmonellosis causes substantial medical and economic burdens worldwide (Voetsch et al., 2004).

Salmonella is a large genus of bacteria including more than 2,300 serotypes, and diagnosis in the majority of laboratories relies on costly and laborious culture screening with both nonselective and selective media (Kilger \& Grimont, 1993). Salmonella species are often detected in sewage, freshwater, marine coastal water, and groundwater. Salmonella spp. can survive for long periods in natural waters (El-Taweel, 1998; Baudart et al., 2000; Shaban \& El-Taweel, 2002 and Samhan, 2005).

A characteristic feature of this organism is its broad host spectrum, which comprises most animal species, including mammals, birds and cold-blooded animals, in addition to humans. Individuals infected with Salmonella shed the organism in their faeces, which enter the domestic sewage that, in turn, may contaminate drinking water sources. Although the concentration of Salmonella in water is low, ingestion of water can still cause infection, because the water may pass rapidly through the stomach into the intestines without stimulating digestion, and thereby escape the natural host defense mechanisms (Murray, 1991). There are several problems concerning the detection of Salmonella in water, such as their low numbers and sometimes intermittent presence, so to determine the presence of Salmonella in environmental and drinking water sources, sensitive and specific detection techniques are needed.

The traditional techniques currently in use are based on cultivation in selective media and identification of the organism by biochemical techniques followed by serotyping (D'Aoust, 1989). These procedures are time-consuming and laborious and several days are required for negative confirmation and at least 2-3 d for a positive confirmation. Further, increased public awareness related to health and economic impact of waterborne contamination and illness has resulted in greater efforts to develop more sensitive methods of pathogenic detection and identification. Therefore, efforts have been made by many workers to reduce time required and to increase the sensitivity of the methods to detect pathogenic bacteria (Carli et al., 2001).

Egypt. J.Microbiol. 45 (2010) 
The uses of the polymerase chain reaction (PCR) to detect pathogenic microorganisms in food, water and clinical specimens have become widely adopted during the last few years.

This study aims to compare between the two conventional techniques (MF and MPN) and the newest one (PCR) for investigation the presence of salmonellae group as pathogenic bacteria in raw River Nile water.

\section{Materials and Methods}

\section{Sampling sites and collection}

River Nile water samples were collected monthly intervals from five sites in Cairo segment from south to north as follow Kafr El-Elw, El-Maasara, El-Giza, Embaba and El-Galatma during one year and other additional sampling sites on Rossita branch (seven sites allocated along $60 \mathrm{~km}$ of Rossita branch which is a point source of pollution named as followed in the front of El-Rahawy drain, Abo El-Khawey (15 km next to El-Rahawy), El-Nigela (30 km next to ElRahawy), Kafr El-Ziat (in the front of Menof drain), salt and soda production company ( $45 \mathrm{~km}, 50 \mathrm{~km}$ and $60 \mathrm{~km}$ next to El-Rahawy drain). Samples were collected from the middle of the river $(30 \mathrm{~cm}$ deep from the surface) in a wide mouth sterile glass bottles. The samples were preserved in an ice box and examined within $2-4 \mathrm{hr}$.

\section{Microbiological examination}

Total bacterial counts were determined by pour plate technique according to APHA (2005). Detection of Salmonella was carried out by MPN and MF techniques according to ISO (2000) and APHA (2005), and nested PCR technique was carried out according to Waage et al. (1999). The samples were diluted with $1 \% \mathrm{NaCl}$ up to $10^{-2}$. One $\mathrm{ml}$ from each dilution was transferred into tube containing buffered peptone water $(9 \mathrm{ml})$ (using five repetitions) and incubated at $37^{\circ} \mathrm{C}$ for $24 \mathrm{hr}$, then $0.1 \mathrm{ml}$ from each tube showing bacterial growth (turbidity) was transferred into $10 \mathrm{ml}$ of Rappaport-Vassiliadis (RV) Broth (LAB M Co.) and incubated at $43.5 \pm 1^{\circ} \mathrm{C}$ for $24 \mathrm{hr}$, then a loop from each tube was taken and streaked out onto bismuth sulfite agar (MERCK Co.). The plates were incubated for $48 \mathrm{hr}$ at $37^{\circ} \mathrm{C}$. While in case of MF technique, $10 \mathrm{ml}$ from each sample were filtered through nitro-cellulose $0.45 \mu \mathrm{m}$ membrane (Whattman Co.), then transferred onto bismuth sulfite agar and incubated for $48 \mathrm{hr}$ at $37^{\circ} \mathrm{C}$ and suspected colonies were confirmed by PCR.

\section{Preparation of water samples for PCR}

The samples were prepared as follows: $1000-2000 \mathrm{ml}$ were filtered with nitro-cellulose membrane $(0.45 \mu \mathrm{m}$ pore size and $47 \mathrm{~mm}$ in diameter (Whattman Co.)). The membrane filters were transferred to $10 \mathrm{ml}$ tryptic soya broth (DIFCO Co.) with $10 \%$ glycerol plates and incubated overnight at room temperature with gently shaking. DNA extractions were carried out according to Kapperud et al. (1993) and Waage et al. (1999), from each overnight culture $100 \mu \mathrm{l}$ were 
transferred into Eppendorf tubes and centrifuged at $13000 \mathrm{rpm}$ for $15 \mathrm{~min}$ in a microcentrifuge (Labfuge, 460). The resulting pellets were resuspended in 50 $\mathrm{\mu l}$ PCR buffer with $1 \mu \mathrm{l}$ of Proteinase $\mathrm{K}\left(0.2 \mathrm{mg} \mathrm{ml}^{-1}\right)$. After incubation at $37^{\circ} \mathrm{C}$ for $1 \mathrm{hr}$, the bacteria were lysed by boiling for $10 \mathrm{~min}$. The samples were stored at $20^{\circ} \mathrm{C}$ overnight prior to PCR. After thawing at room temperature and centrifugation at $14900 \mathrm{xg}$ for $5 \mathrm{~min}, 5 \mu \mathrm{l}$ of supernatant were used for PCR reaction.

\section{Selection and synthesis of primers}

Two pairs of PCR primers were selected according to Waage et al. (1999) from published DNA sequences of a randomly cloned fragment of the Salmonella typhimurium chromosome, two outer primers for the first PCR step were as follows : SAL- 1F, (5'- GTA GAA ATT CCC AGC GGG TAC TG- 3'), SAL- 2R, (5'- GTA TCC ATC TAG CCA ACC ATT GC- 3') and the other two inner primers for second PCR step were as follows SAL- 3F, (5'- TTT GCG ACT ATC AGG TTA CCG TGG- 3'), SAL- 4R, (5'- AGC CAA CCA TTG CTA AAT TGG CGC A- 3'). Primers SAL-1F and SAL-2R were derived from the conserved sequences ST15 and ST11, respectively while Primers SAL-3F and SAL-4R were derived from the conserved sequences ST14 and ST11, respectively.

\section{DNA amplification}

The PCR amplification of the target sequence was performed according to Waage et al. (1999) by the following constituents 1x Taq buffer with $\mathrm{MgCl}_{2}, 200 \mu \mathrm{M}$ dNTPs, $0.1 \mu \mathrm{M}$ for primers and $1 \mathrm{U}$ Taq DNA polymerase in total reaction mixture of $50 \mu \mathrm{l}$. The PCR protocol of first PCR was one cycle at $95^{\circ} \mathrm{C}$ for $3 \mathrm{~min}$, then 40 cycles $\left(95^{\circ} \mathrm{C}\right.$ for $30 \mathrm{sec}, 60^{\circ} \mathrm{C}$ for $1 \mathrm{~min}$ and $72^{\circ} \mathrm{C}$ for $1.5 \mathrm{~min}$ ), one cycle at $72^{\circ} \mathrm{C}$ for $10 \mathrm{~min}$ and then maintain at $4^{\circ} \mathrm{C}$. The nested PCR was carried out in a total volume of $50 \mu \mathrm{l}$. A $1.0 \mu \mathrm{l}$ aliquot of the first PCR product was used as template for nested PCR. The PCR protocol of nested PCR was one cycle at $95^{\circ} \mathrm{C}$ for $3 \mathrm{~min}$, then 20 cycles $\left(95^{\circ} \mathrm{C}\right.$ for $30 \mathrm{sec}, 67^{\circ} \mathrm{C}$ for $1 \mathrm{~min}$ and $72^{\circ} \mathrm{C}$ for $1.5 \mathrm{~min}$ ), one cycle at $72^{\circ} \mathrm{C}$ for $10 \mathrm{~min}$ and then maintain at $4^{\circ} \mathrm{C}$. The PCR products were loaded on $1 \%$ agarose gel with ethidium bromide (Sambrook et. al., 1989) with $\Phi$ X174 HaeIII DNA Marker (Promega Co.).

\section{Statistical analysis}

F ratio obtained by single factor ANOVA was calculated for salmonellae group at five sites at Cairo segment and seven sites at Rossita branch using Microsoft Windows XP, Excel (Office 2003) computer application.

\section{Results and Discussion}

In the present investigation, the total bacterial counts which used as a general picture of bacterial load and salmonellae group, as pathogenic bacteria, were determined in water samples collected from five sites (Kafr El-Elw, El-Maasara, El-Giza, Embaba and El-Galatma) of the River Nile at Cairo segment during one year. In addition of fourteen samples from Rossita branch. 


\section{Total bacterial counts}

Table 1 represents the total bacterial counts at $22^{\circ} \mathrm{C}$ and $37^{\circ} \mathrm{C}$ in samples collected from Cairo segment. The densities of total bacterial counts at $22^{\circ} \mathrm{C}$ and $37^{\circ} \mathrm{C}$ ranged from $1.3 \times 10^{2}-2.2 \times 10^{4} \mathrm{cfu} / \mathrm{ml}$ in samples collected from Kafr ElElw and $1.3 \times 10^{2}-6.1 \times 10^{5} \mathrm{cfu} / \mathrm{ml}$ in samples collected from other sites. Regarding the time of determination, the highest counts were recorded during August in samples collected from all sites. These data revealed a high incidence of microbial load in the Nile water especially; it is going to be used as a water supply for drinking water treatment plants. The higher microbial load in the Nile water at Cairo segment was due to dense population, human activities and industrial centers as a major pollution sources.

TABLE 1. Total bacterial count $\mathrm{cfu} / \mathrm{ml}$ at $22^{\circ} \mathrm{C}$ and $37^{\circ} \mathrm{C}$ in River Nile water at Cairo segment.

\begin{tabular}{|c|c|c|c|c|c|c|c|c|c|c|}
\hline \multirow{2}{*}{ Months } & \multicolumn{2}{|c|}{ Kafr El-Elw } & \multicolumn{2}{|c|}{ El-Maasara } & \multicolumn{2}{|c|}{ El-Giza } & \multicolumn{2}{|c|}{ Embaba } & \multicolumn{2}{|c|}{ El-Galatma } \\
\hline & $22^{\circ} \mathrm{C}$ & $37^{\circ} \mathrm{C}$ & $22^{\circ} \mathrm{C}$ & $37^{\circ} \mathrm{C}$ & $22^{\circ} \mathrm{C}$ & $37^{\circ} \mathrm{C}$ & $22^{\circ} \mathrm{C}$ & $37^{\circ} \mathrm{C}$ & $22^{\circ} \mathrm{C}$ & $37^{\circ} \mathrm{C}$ \\
\hline December & $2.0 \times 10^{3}$ & $1.0 \times 10^{3}$ & $7.0 \times 10^{3}$ & $2.4 \times 10^{2}$ & $7.2 \times 10^{3}$ & $1.8 \times 10^{4}$ & $1.1 \times 10^{5}$ & $4.0 \times 10^{4}$ & $9.0 \times 10^{3}$ & $4.0 \times 10^{3}$ \\
\hline Janı & $2.0 \times 10^{2}$ & $4.0 \times 10^{2}$ & $1.3 \times 10^{2}$ & $4.3 \times 10^{2}$ & $1.6 \times 10^{3}$ & $1.3 \times 10^{2}$ & $9.8 \times 10^{3}$ & $3.6 \times 10^{3}$ & $2.6 \times 10^{3}$ & $1.6 \times 10^{3}$ \\
\hline Feb & $3.0 \times 10^{3}$ & $7.0 \times 10^{2}$ & $1.1 \times 10^{3}$ & $1.8 \times 10^{2}$ & $1.1 \times 10^{5}$ & $1.0 \times 10^{4}$ & $8.6 \times 10^{4}$ & $1.4 \times 10^{4}$ & $9.0 \times 10^{3}$ & $3.0 \times 10^{2}$ \\
\hline March & $1.8 \times 10^{3}$ & $9.0 \times 10^{2}$ & $1.0 \times 10^{3}$ & $3.9 \times 10^{2}$ & $1.8 \times 10^{3}$ & $1.4 \times 10^{3}$ & $1.6 \times 10^{3}$ & $3.7 \times 10^{2}$ & $2.2 \times 10^{3}$ & $1.6 \times 10^{3}$ \\
\hline April & $4.0 \times 10^{3}$ & $1.0 \times 10^{3}$ & $6.0 \times 10^{4}$ & $2.0 \times 10^{3}$ & $4.0 \times 10^{3}$ & $2.0 \times 10^{3}$ & $5.0 \times 10^{4}$ & $4.0 \times 10^{3}$ & $2.0 \times 10^{3}$ & $1.0 \times 10^{3}$ \\
\hline $\mathrm{Ma}$ & $2.0 \times 10^{2}$ & $6.0 \times 10^{2}$ & $8.0 \times 10^{2}$ & $2.2 \times 10^{3}$ & $1.7 \times 10^{4}$ & $8.2 \times 10^{3}$ & $1.0 \times 10^{4}$ & $6.0 \times 10^{3}$ & $2.0 \times 10^{3}$ & $1.4 \times 10^{3}$ \\
\hline June & $3.0 \times 10^{2}$ & $1.0 \times 10^{2}$ & $4.2 \times 10^{3}$ & $6.0 \times 10^{2}$ & $6.8 \times 10^{3}$ & $2.9 \times 10^{3}$ & $4.1 \times 10^{3}$ & $1.8 \times 10^{3}$ & $1.2 \times 10^{3}$ & $4.0 \times 10^{2}$ \\
\hline July & $1.0 \times 10^{3}$ & $7.6 \times 10^{3}$ & $6.0 \times 10^{2}$ & $4.0 \times 10^{2}$ & $4.2 \times 10^{4}$ & $1.2 \times 10^{4}$ & $2.2 \times 10^{4}$ & $1.0 \times 10^{4}$ & $6.0 \mathrm{x}$ & \\
\hline August & $2.2 \times 10^{4}$ & $1.6 \times 10^{4}$ & $1.7 \times 10^{5}$ & $1.3 \times 10^{5}$ & $1.2 \times 10^{5}$ & $1.1 \times 10^{5}$ & $2.8 \times 10^{5}$ & $1.3 \times 10^{5}$ & $6.1 \times 10^{5}$ & $3.1 \times 10^{5}$ \\
\hline September & $1.3 \times 10^{2}$ & $8.7 \times 10^{3}$ & $2.0 \times 10^{2}$ & $9.3 \times 10^{2}$ & $2.3 \times 10^{2}$ & $2.1 \times 10^{2}$ & $4.6 \times 10^{2}$ & $2.2 \times 10^{2}$ & $2.7 \times 10^{2}$ & $1.4 \times 10^{2}$ \\
\hline Oct & $1.0 \times 10^{3}$ & $9.6 \times 10^{2}$ & $1.5 \times 10^{3}$ & $8.1 \times 10^{2}$ & $1.2 \times 10^{3}$ & $3.8 \times 10^{3}$ & $3.9 \times 10^{3}$ & $6.6 \times 10^{3}$ & $1.5 \times 10^{3}$ & $3.6 \times 10^{3}$ \\
\hline nber & $5.2 \times 10^{3}$ & $8.0 \times 10^{2}$ & $2.2 \times 10^{3}$ & $3.7 \times 10^{3}$ & $5.6 \times 10^{3}$ & $1.4 \times 10^{3}$ & $4.5 \times 10^{3}$ & $1.9 \times 10^{3}$ & $6.8 \times 10^{3}$ & $7.6 \times 10^{3}$ \\
\hline Minimum & $1.3 \times 10^{2}$ & $1.0 \times 10^{2}$ & $1.3 \times 10^{2}$ & $1.8 \times 10^{2}$ & $2.3 \times 10^{2}$ & $1.3 \times 10^{2}$ & $4.6 \times 10^{2}$ & $2.2 \times 10^{2}$ & $2.7 \times 10^{2}$ & $1.4 \times 10^{2}$ \\
\hline Maximum & $2.2 \times 10^{4}$ & $1.6 \times 10^{4}$ & $1.7 \times 10^{5}$ & $1.3 \times 10^{5}$ & $1.1 \times 10^{5}$ & $1.1 \times 10^{5}$ & $1.1 \times 10^{5}$ & $1.3 \times 10^{5}$ & $6.1 \times 10^{5}$ & $3.1 \times 10^{5}$ \\
\hline Average & $3.4 \times 10^{3}$ & $3.2 \times 10^{3}$ & $2.0 \times 10^{4}$ & $1.1 \times 10^{4}$ & $2.6 \times 10^{4}$ & $1.4 \times 10^{4}$ & $4.8 \times 10^{4}$ & $1.8 \times 10^{4}$ & $5.3 \times 10^{4}$ & $2.7 \times 10^{4}$ \\
\hline
\end{tabular}

On the other hand, from Table 2 the results of fourteen samples collected from Rossita branch showed that, the average of total viable bacterial counts at $22^{\circ} \mathrm{C}$ and $37^{\circ} \mathrm{C}$ was ranged from $4.0 \times 10^{4}-1.6 \times 10^{8} \mathrm{cfu} / \mathrm{ml}$ in all samples collected from all sites. The increase in total bacterial counts at Rossita branch sites were referred to the presence of two drains (El-Rahawy and Menof) receiving raw sewage and agriculture wastes of the surrounding area.

The average values of Salmonella at Cairo segment by MPN technique was ranged between $5.2 \times 10-2.3 \times 10^{2} \mathrm{MPN}$-index/100ml. While the average values of Salmonella detected by MF technique was ranged between $3.1 \times 10-2.4 \times 10^{2}$ $\mathrm{cfu} / 100 \mathrm{ml}$ during the study period (Table 3 ). The highest densities of Salmonella were found at El-Giza and Embaba sites followed by El-Galatma site and the lower density of Salmonella was at El-Maasara site. 

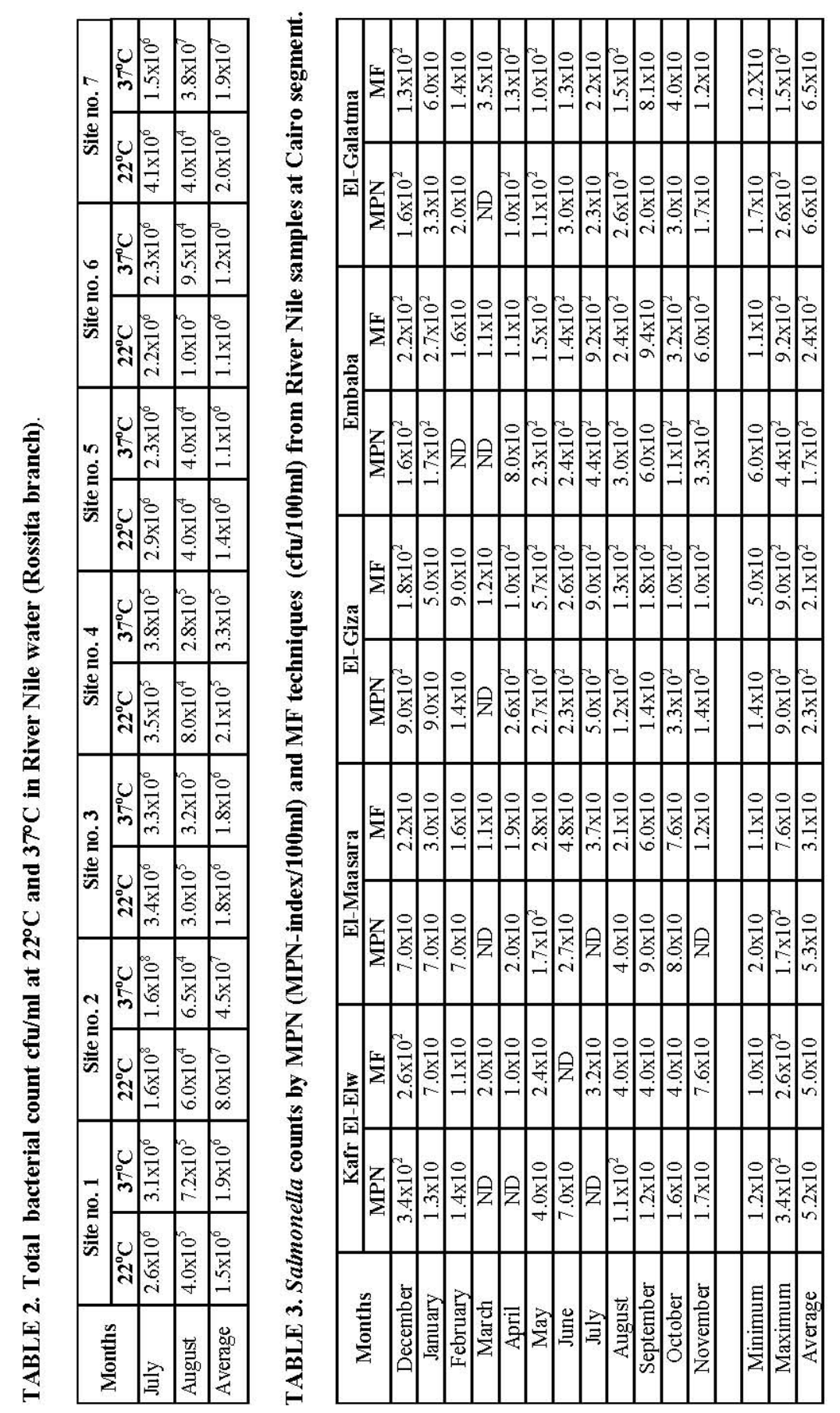

Egypt. J.Microbiol. 45 (2010) 
Salmonella spp. are constantly found in environmental samples, because they are excreted by humans, pets, farm animals and wild life. Municipal sewage, agriculture pollution, and storm water runoff are the main sources of these pathogens in natural waters. It has been suggested that the survival capacity of environmental strains may depend on species and pollution sources (Polo et al., 1998 and Baudart et al., 2000).

While, the average values of Salmonella by MPN technique was ranged between $9.6 \times 10-1.7 \times 10^{3} \mathrm{MPN}$-index/100ml, the average values by MF technique was ranged between $9.0 \times 10-1.8 \times 10^{3} \mathrm{cfu} / 100 \mathrm{ml}$ at Rossita branch (Table 4). The highest density of Salmonella was found at site no. 2 followed by site no. 4 and the lower density of Salmonella at site no. 6. The obtained results of Salmonella were confirmed by the high density of total bacterial counts at the same sites.

The results showed that, Salmonella was detected in 64 out of $74(86.4 \%)$ samples when using MPN technique and 73 out of 74 (98.6\%) samples when using MF technique (including 14 samples of Rossita branch). El-Taweel (1998) studied the presence of salmonellae in water samples collected from River Nile at Cairo segment in eight sampling sites along $60 \mathrm{~km}$ during two years. He found that, the highest frequencies $\left(1.4 \times 10^{3}-2.6 \times 10^{3} \mathrm{cfu} / 100 \mathrm{ml}\right)$ of salmonellae isolation were obtained at El-Gezira site, Farouk Corner and Damietta branch sites. While the average counts recorded at the other sites were between $3.1 \times 10^{2}$ and $5.8 \times 10^{2} \mathrm{cfu} / 100 \mathrm{ml}$ and he added that salmonellae were detected in 25 out of 32 (78\%) samples by MF technique during the study period. Ali et al. (2000), ElTaweel \& Shaban (2001) and Kamel et al. (2006) recorded similar results and they concluded that the high counts of salmonellae may be referred to municipal and food processing waste discharge along the main stream of the River Nile and its branches.

Waterborne diseases have been a major global health problem throughout history. Pathogens are constantly released at variable concentrations from infected humans, pets, farm animals and wildlife (Geldriech, 1996). Municipal sewage and storm water runoff become the conduits for the passage of pathogens into surface waters (O'Shea \& Field, 1992 and Irvine et al., 1995). It was shown that the annual bacterial loads of Salmonella in rivers and coastal areas could be very important (O' Shea \& Field, 1992 and Irvine et al., 1995). 


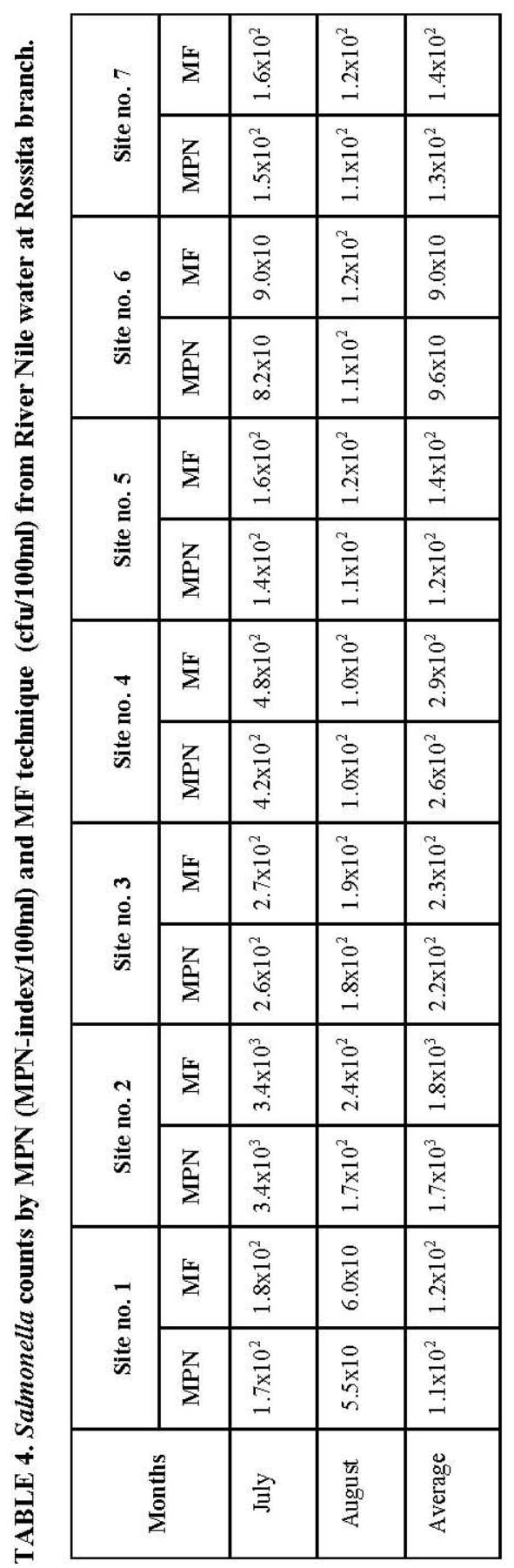

Egypt. J.Microbiol. 45 (2010) 
The first PCR step amplifies a fragment with an estimated size of $438 \mathrm{bp}$, while the size of the final PCR product is 312 bp. Salmonella was positive in 74 out of $74(100 \%)$ samples by nested PCR where 10 out of $74(13.5 \%)$ were positive by first PCR. All water samples were positive nested PCR (Fig. 1 and 2). 19 random isolates out of 19 (100\%) were positive when confirmed by PCR.

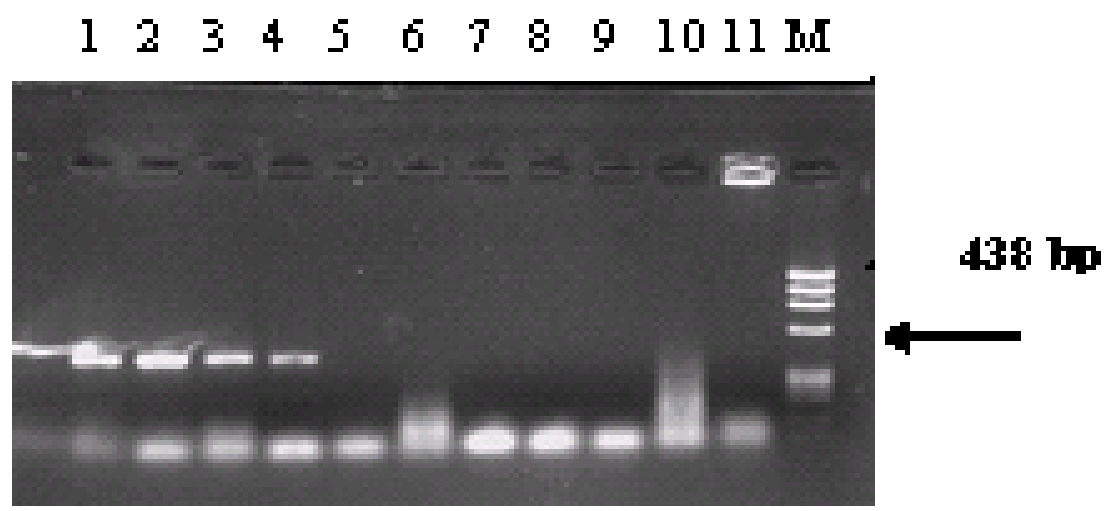

Fig. 1. Gel electrophoresis of first PCR lane1: positive control, lane 2: Kafr Elw, lane 3: El-Massara, lane 4: El-Giza, lane 5: Kafr El-Elw, lane6: ElMassara, lane 7: El-Giza, lane 8: Kafr El-Elw, lane9: El-Massara, lane10: El-Giza, lane11: Embaba, M: Marker (ØX 174).

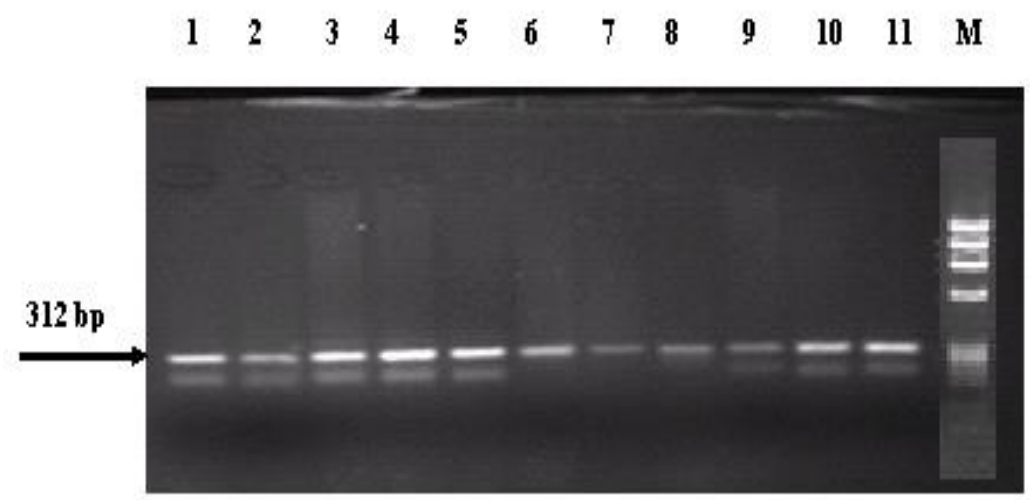

Fig. 2. Gel electrophoresis of nested PCR lane 1: positive control, lane 2: Kafr Elw, lane 3: El-Massara, lane 4: El-Giza, lane 5: Kafr El-Elw, lane 6: El-Massara, lane 7: El-Giza, lane 8: Kafr El-Elw, lane 9: El-Massara, lane 10: El-Giza, lane11: Embaba, M: Marker (ØX 174). 
It can be conclude that, comparison between results of detection of Salmonella by MPN technique, MF technique and PCR techniques are difficult and puzzle. MPN technique is less sensitive $(86.4 \%)$ than the two other techniques, it may due to presence of more than one selective constitutes in RV medium which inhibit for some species of Salmonella itself. On the other hand, there is no significant change between results of MF technique $(98.3 \%$ \& $100 \%)$ and nested PCR technique (100\%), while first PCR $(0.0 \%$ \& 16.6\%) which is less sensitive than nested PCR (Table 5), so the nested approach was chosen to improve the specificity of the assay (Steffan \& Atlas, 1991). Any non-specific PCR products produced during the first step of the PCR will not be amplified during the second step due to lack of complementarily to inner primer sequences. The sensitivity of the assay is also improved by use of nested PCR. Subdetectable levels of PCR products generated during the first step of the PCR are amplified to reach detectable levels during the second step. A 10000-fold increase in sensitivity has been reported (Arias et al., 1995). In addition, any inhibitory substances present will be diluted, since only $1 / 100$ of the reaction mixture of the first PCR step is transferred into the second reaction mixture.

TABLE 5. Salmonella presence in raw River Nile water by MPN, MF and nested PCR techniques.

\begin{tabular}{|l|c|c|c|c|c|}
\hline \multicolumn{1}{|c|}{ Samples } & \multirow{2}{*}{$\begin{array}{c}\text { Number of } \\
\text { samples }\end{array}$} & \multirow{2}{*}{$\begin{array}{c}\text { MPN } \\
\text { technique }\end{array}$} & \multirow{2}{*}{$\begin{array}{c}\text { MF } \\
\text { technique }\end{array}$} & \multicolumn{2}{c|}{$\begin{array}{c}\text { Nested PCR } \\
\text { technique }\end{array}$} \\
\cline { 5 - 6 } & 60 & 50 & $\begin{array}{c}59 \\
\text { First }\end{array}$ & Second \\
\hline $\begin{array}{l}\text { River Nile } \\
\text { Cairo segment }\end{array}$ & & $(83.3 \%)$ & $(98.3 \%)$ & $(16.6 \%)$ & $\begin{array}{c}60 \\
(100 \%)\end{array}$ \\
\hline Rossita branch & 14 & $\begin{array}{c}14 \\
(100 \%)\end{array}$ & $\begin{array}{c}14 \\
(100 \%)\end{array}$ & $\begin{array}{c}0.0 \\
(0.0 \%)\end{array}$ & $\begin{array}{c}14 \\
(100 \%)\end{array}$ \\
\hline
\end{tabular}

Jyoti et al. (2010) found that the site no. 3 (Nishat Ganj Bridge) exhibits highest number of the Salmonella spp. $\left(1.19 \times 10^{9} \mathrm{cfu} / 100 \mathrm{ml}\right)$ harboring invA gene in comparison to other sampling locations in the river Gomti at Lucknow. Also, the surface water samples from the river Ganga, Yamuna and their confluence point at Allahabad were also positive for Salmonella spp. (1.57 $\times 10^{5}$ $\left.1.33 \times 10^{4} \mathrm{cfu} / 100 \mathrm{ml}\right)$. The high vulnerability to waterborne Salmonella infections in Asia and other developing countries is due to scarcity of potable water and dependence of a large population on natural resources for daily water requirement (Moganedi et al., 2007). The runoff from fields with animal husbandry, addition of untreated sewage from nearby civilization contributes Salmonella in natural water resources (Moganedi et al., 2007 and Jenkins et al., 2008).

\section{Statistical analysis}

Statistical analysis were occurred only between MF and MPN techniques due to PCR technique doesn't provide counts to involved in statistical analysis (provide only positive and negative results). F ratios obtained by single factor ANOVA for Salmonella determined by MF and MPN between different sites at

Egypt. J.Microbiol. 45 (2010) 
Cairo segment and Rossita branch were represented in Table 6. Results indicated that counts of Salmonella showed significant differences between sites using both techniques (MF and MPN) at Cairo segment. Wherever, no significant difference between sites at Rossita branch may be due to sampling number is low. From these results, it can be concluded that, significantly there is no difference when we compared MF with MPN techniques, it may be return to the ratio between negative to positive samples (Table 6).

TABLE 6. Analysis of Variance (ANOVA) for Salmonella detection by MF and MPN techniques from different sites at Cairo segment (during one year) and Rossita branch.

\begin{tabular}{|l|c|c|c|c|c|}
\hline \multirow{2}{*}{ Sampling sites } & Techniques & Sample source & df & F & P \\
\hline Cairo segment & MPN & Between sites & 4 & 4.30 & 0.0042 \\
\cline { 2 - 6 } & MF & Between sites & 4 & 4.26 & 0.0045 \\
\hline Rossita branch & MPN & Between sites & 6 & 1.01 & 0.4857 \\
\cline { 2 - 6 } & MF & Between sites & 6 & 1.08 & 0.4527 \\
\hline
\end{tabular}

*Significant at $\leq 5 \%$ level; other F ratios not significant.

Finally, MF technique is more suitable to detect salmonellae as it allows to filter or pass relatively larger amount of water sample rather than MPN which measure salmonellae presence in fixed amount of water while nested PCR technique is more rapid, sensitive and specific than conventional technique (MF and MPN). In the future the authors recommend using quantitative PCR technique for monitoring of pathogens in surface water which affects water treatment processes in drinking water treatment plants.

\section{References}

Ali, G.H., El-Taweel, G.E. Ghazy, M.M. and Ali, M.A. (2000) Microbiological and chemical study of the River Nile water quality. International Journal of Environmental Studies, 58, 47-69.

APHA (American Public Health Association) (2005) In: "Standard Techniques for the Examination of Water and Wastewater", Clesceri, L.S., Greenberg, A.E., Eaton, A.D. (Ed.) $21^{\text {th }}$ ed. American Public Health Association, Washington", DC.

Arias, C.R., Garay, E. and Aznar, R. (1995) Nested PCR technique for rapid and sensitive detection of Vibrio vulnificus in fish, sediments and water. Applied and Environmental Microbiology, 61, 3476-3478.

Baudart, J., Lemarchand, K., Brisabois, A. and Lebaron, P. (2000) Diversity of Salmonella strains isolated from aquatic environment as determined by serotyping and amplification of the ribosomal DNA spacer regions. Applied and Environmental Microbiology, 66, 1544-1552. 
Carli, K.T., Unal, C.B., Caner, V. and Eyigor, A. (2001) Detection of salmonellae in chicken faeces by a combination of tetrathionate broth enrichment, capillary PCR, and capillary gel electrophoresis. Journal of Clinical Microbiology , 39,1871-1886.

Crump, J.A., Luby, S.P. and Mintz, E.D. (2004) The global burden of typhoid fever. Bull World Health Organ. 82, 346-353.

D’Aoust, J.Y. (1989) Salmonella. In : "Foodborne Bacterial Pathogens" Doyle, M.P. (Ed.), pp. 327- 445. New York: Marcel Dekker.

El-Taweel, G.E. (1998) Microbiological profile of raw River Nile water. Journal of Egyptian Public Health Association LXXIII, 449-477.

El-Taweel, G.E. and Shaban, A.M. (2001) Microbiological quality of drinking water at eight water treatment plants. International Journal of Environmental Health and Research, 11, 285-290.

Geldriech, E.E. (1996) Pathogenic agents in fresh water resources. Hydrological Processes, 10, 315- 333.

Irvine, K.N., Pettibone, G.W. and Droppo, I.G. (1995) Indictor bacteria-sediment relationships: Implications for water quality modeling and monitoring, In: "Modern Techniques for Modeling the Management of Storm Water Impacts". W. Hames (Ed.) pp. 205-230. Computational Hydraulics International, Guelph, Ontario, Canada.

ISO. (2000) Water quality. Detection and enumeration of Salmonella. International Organization for Standardization, Geneva. Edition 1 Stage: 90.92 TC 147/SC4 ICS 07100.20.

Jenkins, M.B., Endale, D.M. and Fisher, D.S. (2008) Most probable number methodology for quantifying dilute concentrations and fluxes of Salmonella in surface waters. Journal of Applied Microbiology, 104, 1562-1568.

Jyoti, A., Ram, S., Vajpayee, P., Singh, G., Dwivedi, P.D., Jain, S.K. and Shanker, R. (2010) Contamination of surface and potable water in South Asia by salmonellae. Culture-independent quantification with molecular beacon real-time PCR . Science of the Total Environment , 408, 1256-1263.

Kamel, M.M., El-Taweel, G.E. and Shaban, A.M. (2006) Microbiological monitoring of El- Salam Canal, Sinai, Egypt. Journal of Environmental Sciences, 31, 109-127.

Kapperud, G., Vardund, T., Skjerve, H. and Michaelsen, E.T.E. (1993) Detection of pathogenic Yersinia enterocolitica in foods and water by immunomagnatic separation, nested polymerase chain reactions, and colorimetric detection of amplified DNA. Applied and Environmental Microbiology, 59, 2938-2944.

Kilger, G. and Grimont, P.A.D. (1993) Differentiation of Salmonella phase 1 flagellar antigen types by restriction of the amplified fliC gene. Journal of Clinical Microbiology, 31, 1108-1110. 
Malorny, B., Löfström, C., Wagner, M., Krämer, N. and Hoorfar, J. (2008) Enumeration of Salmonella bacteria in food and feed samples by real-time PCR for quantitative microbial risk assessment. Applied and Environmental Microbiology, 74,1299-1304.

Moganedi, K.L.M., Goyvaerts, E.M.A., Venter, S.N. and Sibara, M.M. (2007) Optimization of the PCR-invA primers for the detection of Salmonella in drinking and surface waters following a pre-cultivation step. Water SA, 33, 95-202.

Murray, C.J. (1991) Salmonellae in the environment. Revue Scientifique et Technique. Office International des Epizooties , 10, 765-785.

O' Shea, M.L. and Field, R. (1992) Detection and disinfection of pathogens in stormgenerated flows. Canadian Journal of Microbiology, 38, 267-276.

Polo, F., Figueras, M.J., Inza, I., Sala, J., Fleisher, J.M. and Guarro, J. (1998) Relationship between presence of Salmonella and indicators of feacal pollution in aquatic habitats.FEMS Microbiology Letters , 15, 253-256.

Sambrook, J., Fritsch, E.F. and Maniatis, T. (1989) "Molecular Cloning: a Laboratory Manual", $2^{\text {nd }}$ ed. Cold Spring Harbor, NY: Cold Spring Harbor Laboratory Press.

Samhan, F.A. (2005) Coliphage as indicators and test organisms for assessment of hygienic safety of water, waste water and liquid organic waste. Ph. D Thesis, VERLAG GRAUER, Beuren, Stuttgart. ISBN 3.86186-503.3.

Shaban, A.M., and El-Taweel, G.E. (2002) Reduction of indicators and pathogenic bacteria through waste water treatment plant. Egyptian Journal of Microbiology, 37, 157-172.

Steffan, R.J., and Atlas, R.M. (1991) Polymerase chain reaction: applications in environmental microbiology. Annual Revision of Microbiology , 45, 137-161.

Voetsch, A.C., Gilder, T.J.V., Angulo, F.J., Farley, M.M., Shallow, S. and Marcus, R. (2004) Food Net estimate of the burden of illness caused by non-typhoidal Salmonella infections in the United States. Clinical Infectious Diseases, 38, S127-134.

Waage, A.S., Vardund, L. and Kapperud, G. (1999) Detection of low numbers of Salmonella in environmental water, sewage and food samples by a nested polymerase chain reaction assay. Journal of Applied Microbiology, 87, 418-428.

(Received 20/ 7/2010; accepted 17/10/2010) 
جميلـه السيد الطويل, طارق عبد الموجود موسىثى, فرج أحمد سمحان, وليد

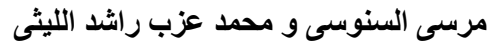

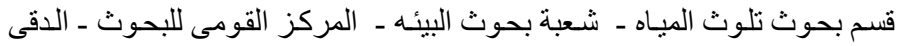

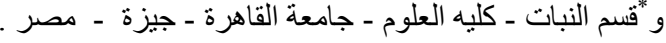

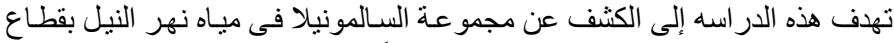

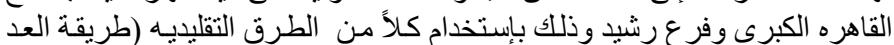

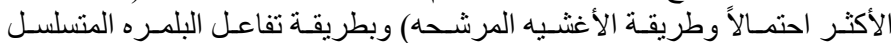

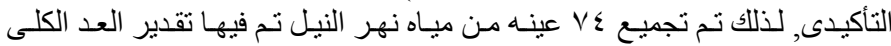

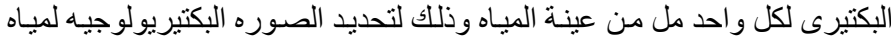

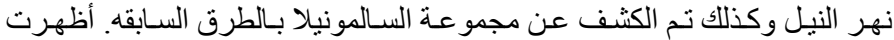

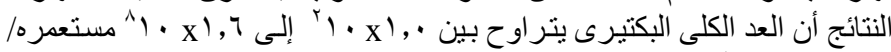
واحد مل وذلك أثناء فترة الدر اسهـ.

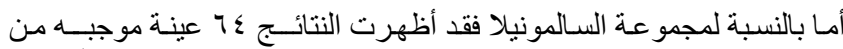

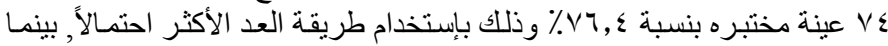

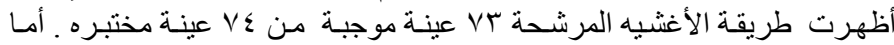

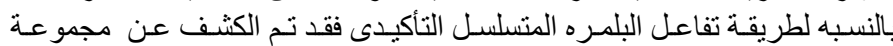
السالمونيلا فى كل العينات (ع V عينة).

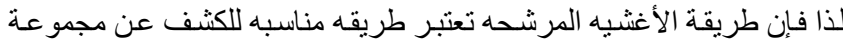

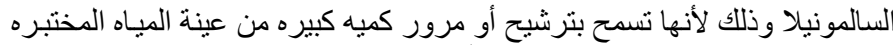

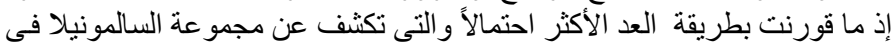

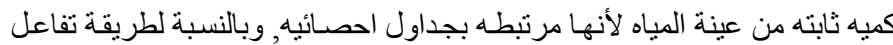

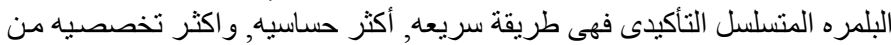

الطرق التقليديه مثل ( طريقة الأغشيه المرشحه وطريقة الترئة العد الأكثر احتمالاً).

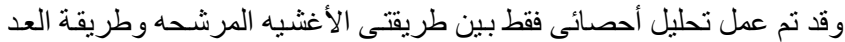

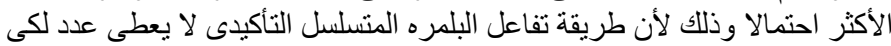

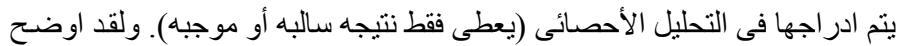

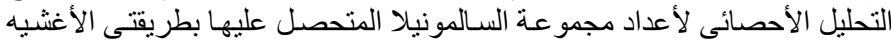

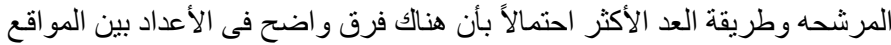

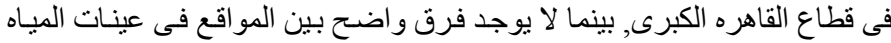

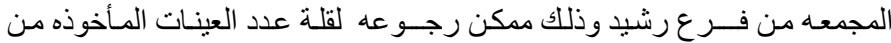
هــا الموقع.

ولذلك توصى الدر اسه بإستخدام تفاعل البلمره المتسلسل الكمى لتحديد الأعداد

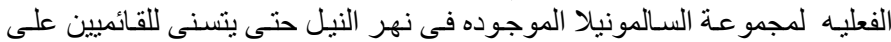

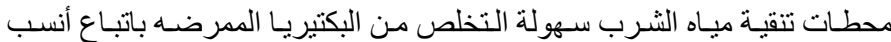

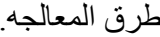

Egypt. J.Microbiol. 45 (2010) 